\title{
ANALISIS KECEMASAN PADA PASIEN PREOPERASI APENDISITIS DI RUANG RAWAT INAP RUMAH SAKIT UMUM DAERAH SITI AISYAH KOTA LUBUKLINGGAU TAHUN 2019
}

\author{
Bambang Soewito \\ Dosen Prodi Keperawatan Lubuklinggau \\ Email : bambangsoewito1974@gmail.com \\ Sulaiman \\ Dosen Jurusan Keperawatan Palembang \\ Email : sulaimanzakaria14@gmail.com
}

\begin{abstract}
ABSTRAK
Latar BelakangApendiksitis adalah peradangan dari apendik periformis, dan merupakan penyebab abdomen akut yang paling sering.Istilah usus buntu yang dikenal di masyarakat awam adalah kurang tepat karena usus yang buntu sebenarnya adalah sekum.Apendisitis diperkirakan ikut serta dalm system imun sektorik di saluran pencernaan.Namun, pengangkatan apendiks tidak menimbulkan efek fungsi system imun yang jelas. Tujuan dari penelitian: untuk mengetahui hubungan antara pengetahuan, pendidikan, umur dan ekonomi secara simultan dengan kecemasan pada pasien pre operasi appendisitis di ruang rawat inap Rumah Sakit Umum Daerah Siti Aisyah Kota Lubuklinggau tahun 2019. Desain penelitian: Desain penelitian ini adalah kuantitatif yang menggunakan metode survei analitik dengan pendekatan cross sectional. Populasi dalam penelitian ini adalah seluruh pasien appendisitis yang dirawat di Ruang Rawat Inap Rumah Sakit Umum Daerah Siti Aisyah Kota Lubuklinggau tahun 2019 pada saat penelitian dilakukan yang diperkiraan berjumlah 127 orang. Hasil Penelitian: Berdaarkan Uji statistik dengan metode ChiSquare di dapatkan hasil yang didapatkan yaitu ada hubungan antara pengetahuan secara parsial dengan kecemasan pada pasien pre operasi appendisitis dengan $\rho$-value $=0,00$.

Ada hubungan antara pendidikan dengan kecemasan pada pasien pre operasi appendisitis dengan $\rho$-value $=0,019$.Ada hubungan antara umur dengan kecemasan pada pasien pre operasi appendisitis dengan $\rho$-value $=0,003$. Ada hubungan antara faktor ekonomidengan kecemasan pada pasien pre operasi appendisitis dengan $\rho$-value $=0,002$. Dan hasil uji statistik multivariat diperoleh variabel yang berhubungan bermakna adalah umur $(5,135)$ dan ekonomi $(0,148)$.Dan variabel yang paling dominan berhubungan bermakna adalah variabel umur. Kesimpulan: Saran kepada pihakRumah Sakit Umum Daerah Siti Aisyah Kota Lubuklinggau, khususnya bagi perawat untuk meningkatkan kinerja perawat dalam mencegah atau mengurangi kecemasan pasien sebelum dilakukan operasi apendisitis.
\end{abstract}

Kata Kunci: Pengetahuan, pendidikan, umur, ekonomi, kecemasan, apendisitis

\section{ABSTRACT}

Background: Appendixitis is inflammation of the appendix periformis, and is the most common cause of acute abdomen. The term appendicitis which is known in ordinary people is less precise because the appendix is actually a cecum. Appendicitis is thought to participate in the sectoral immune system in the digestive tract. However, removal of the 
appendix does not cause a clear effect of immune system function. The purposes of this study: The purpose of this study was to determine the relationship between knowledge, education, age and economy simultaneously with anxiety in patients with preoperative appendicitis in the inpatient area of the Siti Aisyah Regional Hospital in Lubuklinggau City in 2019. Research methods The design of this research is quantitative which uses analytic survey method with cross sectional approach. The population in this study were all appendicitis patients who were treated in the Inpatient Room of the Siti Aisyah Regional Hospital in Lubuklinggau City the year at the time of the study which was estimated at 127 people. The results: Based on statistical tests using the Chi-Square method the results obtained are that there is a relationship between knowledge partially with anxiety in patients with preoperative appendicitis with $\rho$-value $=0.00$. There is a relationship between partial education with anxiety in patients with preoperative appendicitis with $\rho$-value $=$ 0.019. There is a relationship between age partially with anxiety in patients with preoperative appendicitis with $\rho$-value $=0.003$. There is a relationship between economic factors partially with anxiety in patients with preoperative appendicitis with $\rho$-value $=$ 0.002. And the results of multivariate statistical tests obtained variables that were significantly associated simultaneously were age $(5,135)$ and economy $(0.148)$. And the most dominant variable related significantly is the age variable. Conclusion: Suggestions to the Siti Aisyah Regional General Hospital Lubuklinggau, especially for nurses to improve the performance of nurses in preventing or reducing patient anxiety before appendicitis surgery.

\section{Keyword : Knowledge, education, age, economics, difficulties, appendicitis}

\section{PENDAHULUAN}

Penyakit inflamasi pada system pencernaan sangat banyak, diantaranya appendisitis dan divertikular disease.Apendiksitis adalah suatu penyakit inflamasi pada apendiks diakibanya terbuntunya lumen apendiks.Divertikular disease merupakan penyakit inflamasi pada saluran cerna terutama kolon.Keduanya merupakan penyakit inflamasi tetapi penyebabnya berbeda. Appendiksitis disebabkan terbuntunya lumen apendiks.dengan fecalit, benda asing atau karena terjepitnya apendiks, sedang diverticular disebabkan karena massa feces yang terlalu keras dan membuat tekanan dalam lumen usus besar sehingga membentuk tonjolan-tonjolan divertikula dan divertikula ini yang kemudian bila sampai terjepit atau terbuntu akan mengakibatkan diverticulitis ${ }^{5}$

Apendiksitis adalah peradangan dari apendik periformis, dan merupakan penyebab abdomen akut yang paling sering (Dermawan \& Rahayuningsih, 2014).Istilah usus buntu yang dikenal di masyarakat awam adalah kurang tepat karena usus yang buntu sebenarnya adalah sekum.Apendiks diperkirakan ikut serta dalm system imun sektorik di saluran pencernaan. Namun, 
pengangkatan apendiks tidak menimbulkan efek fungsi system imun yang jelas. Peradangan pada apendiks selain mendapat intervensi farmakologik juga memerlukan tindakan bedah segera untuk mencegah komplikasi dan memberikan implikasi pada perawat dalam bentuk asuhan keperawatan ${ }^{13}$

Komplikasi utama pada appendiksitis adalah perforasi apendiks yang dapat berkembang menjadi peritonitis atau abses.Insidens perforasi berkisar $10 \%$ sampai $32 \%$. Insidens lebih tinggi pada anak kecil dan lansia ${ }^{11}$

Di Asia indisdensi appendiksiti pada tahun 2017 adalah 4,8\% penduduk dari total populasi sebanyak 127 orang Sedangkan dari hasil Survey Kesehatan Rumah Tangga (SKRT Tahun 2013 di indonesia,appendiksitis akut merupakan salah satu penyebab dari akut abdomen danbeberapa indikasi untuk dilakukan operasi kegawatdaruratan abdomen. Insidens appendiksitis di Indonesia menempati urutan tertinggi di antara kasus kegawatan abdomen lainya, pada tahun 2013 jumlah penderita appendiksitis di indonesia mencapai 591.819 orang dan meningkat pada tahun 2014 sebesar 596.132 orang $^{2}$

Dinas Kesehatan Provinsi Sumatera Selatan menyebutkan padatahun 2015 jumlah kasus apendisitis di Provinsi
Sumatera Selatan sebanyak 5.980 penderita,dan 177 penderita diantaranya menyebabkan kematian. Dari kasus appendiksitis diketahui (31,3\%) kasus memiliki appendiksitis perforasi, sementara $(69,7 \%)$ kasus memiliki appendiksitis sederhana ${ }^{7}$

Di Kota Lubuklinggau berdasarkan data dari rumah sakit umum daerah Siti Aisyah dalam 3 tahun terakhir angka kejadian penyakit appendiksitis masih cukup tinggi, pada tahun 2016 angka kejadian apendisitis berjumlah 67 orang $(24,5 \%)$, tahun 2017angka kejadian apendisitis berjumlah 67 orang (24,5\%), pada tahun 2018 terjadi peningkatan yang sangat signifikan angka kejadian apendisitis yaitu berjumlah 127 orang $(51,0 \%)^{12}$

Faktor-faktor yang mempengaruhi keterlambatan penanganan appendiksitis akut dapat mengakibatkan timbulnya komplikasi.Faktor-faktor tersebut dapat berasal dari pasien maupun dari tenaga medis.Faktor yang berasal dari pasien meliputi pengetahuan dan mahalnya biaya yang harus dikeluarkan.Sedangkan faktor keterlambatan penanganan yang berasal dari tenaga medis adalah kesalahan diagnosis, keterlambatan merujuk ke rumah sakit, dan penundaan tindakan bedah ${ }^{10}$ 
Dalam mendiagnosis appendiksitis, sering terjadi kesulitan dikarenakan adanya beberapa pasien yang menunjukkan gejala dan tanda yang tidak khas, sehingga dapat menyebabkan kesalahan dalam mendiagnosis sehingga dapat memperburuk prognosis dari penyakit itu sendiri. Dalam mendiagnosis appendiksitis, anamnesis dan pemeriksaan memegang peranan utama dengan akurasi $76-80 \%$, tetapi dalam mencegah pasien agar tidak terjadi perforasi tidaklah cukup hanya dengan anamnesis dan pemeriksaan fisik. Dapat juga dilakukan Ultrasonography (USG) dan Computed Tomography (CT) scan, tetapi dikarenakan alat ini memerlukan biaya yang tidak murah dan tidak semua unit pelayanan memilikinya, sehingga pemeriksaan ini masih jarang untuk dilakukan ${ }^{18}$

Menurut Ludeman, (2016)sistem penanganan pada pasien apendisitis yaitu, pengobatan yang paling baik adalah operasi appendiks. Dalam waktu 48 jam harus dilakukan. Penderita di obsevarsi, istirahat dalam posisi fowler, diberikan antibiotik dan diberikan makanan yang tidak merangsang peristaltik, jika terjadi perforasi diberikan drain diperut kanan bawah.Perawat perlu memprioritaskan keperawatan yang dilakukan yaitudengan menghilangkan nyeri, mencegah terjadinya komplikasi, dan memberikan informasi tentangkondisi atau prognosis dan kebutuhan pengobatannya.

Operasi adalah pengalaman baru bagi pasien yang menimbulkan kecemasan, respon pasien ditujukan melalui ekspresi marah, bingung, apatis atau mengajukan pertanyaan.Kemampuan komunikasi terapeutik penting dalam mengidentifikasi dan mengatasi kecemasan pasien preoperasi.Kecemasan dapat dikurangi dengan tindakan keperawatan fokus pada komunikasi terapeutik bagi pasien dan keluarganya.

Kecemasan adalah satu perasaan subjektif yang dialami seseorang terutama oleh adanya pengalaman baru, termasuk pada pasien yang akan mengalami tindakan invasif seperti pembedahan. Dilaporkan pasien mengalami cemas karena hospitalisasi, pemeriksaan dan prosedur tindakan medik yang menyebabkan perasaan tidak nyaman seperti tindakan pro operasi apendiksitis $^{2}$

\section{Tujuan Penelitian}

\section{Tujuan Umum}

Diketahuihubungan antara faktor pengetahuan, pendidikan, umur dan ekonomi secara simultan dengan kecemasan pada pasien pre operasi 
appendisitis di ruang rawat inap Rumah

Sakit Umum Daerah Siti Aisyah Kota

Lubuklinggau tahun 2019.

\section{Tujuan Khusus}

a. Diketahui hubungan antara faktor pengetahuan secara parsial dengan kecemasan pada pasien pre operasi appendisitis di ruang rawat inap Rumah Sakit Umum Daerah Siti Aisyah Kota Lubuklinggau tahun 2019.

b. Diketahui hubungan antara faktor pendidikan secara parsial dengan kecemasan pada pasien pre operasi appendisitis di ruang rawat inap Rumah Sakit Umum Daerah Siti
Aisyah Kota Lubuklinggau tahun 2019.

c. Diketahui hubungan antara faktor umur secara parsial dengan kecemasan pada pasien pre operasi appendisitis di ruangrawat inap Rumah Sakit Umum Daerah Siti Aisyah Kota Lubuklinggau tahun 2019.

Diketahui hubungan antara faktor ekonomi secara parsial dengan kecemasan pada pasien pre operasi appendisitis di ruang rawat inap Rumah Sakit Umum Daerah Siti Aisyah Kota Lubuklinggau tahun 2019.

\section{HASIL PENELITIAN}

\section{Analisis Univariat}

Distribusi Frekuensi RespondenBerdasarkan Pengetahuan Pada Pasien Pre Op Operasi Apendiksitsi Ruang Rawat Inap Rumah Sakit Siti Aisyah Kota Lubuklinggau Tahun 2019 Tabel 1.

Distribusi Frekwensi Responden berdasarkan Pengetahuan pada pasien Pre Op operasi Apendiksitis di Ruang Rawat inap

\begin{tabular}{|c|c|c|c|}
\hline No & Pengetahuan & Jumlah & Persentase \\
\hline 1 & Baik & 16 & 34.8 \\
\hline 2 & Kurang & 30 & 62.2 \\
\hline \multicolumn{2}{|c|}{ Jumlah } & 46 & 100 \\
\hline
\end{tabular}

Dari tabel diatas distribusi pengetahuan pasien didapatkan bahwa sebagian besar responden mempunyai tingkat pengetahuan yang kurang yaitu sebanyak 30 responden $(62.2 \%)$. 
Tabel 3.

Distribusi Frekuensi Responden Berdasarkan Pendidikan Pada Pasien Pre Op Apendiksitis di Ruang Rawat Inap Rumah Sakit Siti Aisyah Kota Lubuklinggau Tahun 2019

\begin{tabular}{|c|c|c|c|}
\hline No & Pendidikan & Jumlah & Persentase \\
\hline 1 & Tinggi & 18 & 39.1 \\
\hline 2 & Rendah & 28 & 60.9 \\
\hline \multicolumn{2}{|c|}{ Jumlah } & 46 & 100 \\
\hline
\end{tabular}

Dari tabel diatas distribusi tingkatan umur yang beresiko yaitu sebanyak 28 umur pasien didapatkan bahwa sebagian responden $(60.9 \%)$.

besar responden mempunyai tingkatan

Distribusi Frekuensi Responden Berdasarkan Umur Pada Pasien Pre Op Apendiksitis di Ruang Rawat Inap Rumah Sakit Siti Aisyah Kota Lubuklinggau Tahun 2019

Tabel 3

Distribusi frekwensi responen berdasarkan Umur pada pasien pre op operasi apendiksitis di ruang rawat inap

\begin{tabular}{|c|c|c|c|}
\hline No & Umur & Jumlah & Persentase \\
\hline 1 & Beresiko & 28 & 60.9 \\
\hline 2 & Tidak beresiko & 18 & 39.1 \\
\hline \multicolumn{2}{|c|}{ Jumlah } & 46 & 100 \\
\hline
\end{tabular}

Dari tabel diatas distribusi tingkatan tingkatanumur yang beresiko yaitu umur pasien didapatkan bahwa sebagian sebanyak 28 responden $(60.9 \%)$.

besar responden mempunyai

Distribusi Frekuensi Responden Berdasarkan Ekonomi Pada Pasien Pre Op Apendiksitis di Ruang Rawat Inap Rumah Sakit Siti Aisyah Kota Lubuklinggau Tahun 2019

Tabel 4

Distribusi berdasarkan ekonomi pada pasien pre operasi apendiksitis di ruang rawat inap

\begin{tabular}{|c|c|c|c|}
\hline No & Ekonomi & Jumlah & Persentase \\
\hline 1 & Tinggi & 20 & 43.5 \\
\hline 2 & Rendah & 46 & 56. \\
\hline \multicolumn{2}{|c|}{ Jumlah } & 46 & 100 \\
\hline
\end{tabular}

Dari tabel diatas distribusi tingkat tingkat ekonomi yang rendah yaitu ekonomi pasien didapatkan bahwa sebanyak 26 responden $(56.5 \%)$. sebagian besar responden mempunyai 
Tabel 4

Distribusi Frekuensi Responden Berdasarkan Kecemasan Pada Pasien Pre Op Apendiksitis di Ruang Rawat Inap Rumah Sakit Siti Aisyah Kota Lubuklinggau Tahun 201

\begin{tabular}{|c|c|c|c|}
\hline No & $\begin{array}{c}\text { Kecemasan pada pasien } \\
\text { pre Op Apendiksitis }\end{array}$ & Jumlah & Persentase \\
\hline 1 & Ya & 31 & 67.4 \\
\hline 2 & Tidak & 15 & 32.6 \\
\hline \multicolumn{2}{|c|}{ Jumlah } & 46 & 100 \\
\hline
\end{tabular}

Dari tabel diatas distribusi kecemasan pada pasien pre op apendisitis didapatkan bahwa sebagian besar responden mempunyai tingkat kecemasan yaitu sebanyak 31 responden $(67.4 \%)$.

\section{Analis bivariat}

Analisa ini dilakukan untuk mengetahui apakah ada hubungan antara variabelindependen (Pengetahuan, pendidikan, umur dan ekonomi) dengan variabel dependen (Kecemasan pada pasien pre op apendisitis)dengan menggunakan uji statistik "Chi Square" untuk lebih jelasnya dapat dilihat pada tabel berikut

\section{Tabel 5.6}

Distribusi frekwensi Responden berdasarkan faktor pengetahuan yang mempengaruhi kecemasan pada pasien op operasi apendiksitis di ruang rawat inap

\begin{tabular}{|c|c|c|c|c|c|c|c|c|c|}
\hline \multirow[t]{3}{*}{ No } & \multirow[t]{3}{*}{ Pengetahuan } & \multicolumn{4}{|c|}{$\begin{array}{l}\text { Kecemasan pada pasien } \\
\text { pre op apendiksitis }\end{array}$} & \multirow{2}{*}{\multicolumn{2}{|c|}{ Jumlah }} & \multirow{2}{*}{$\begin{array}{c}\rho \\
\text { value }\end{array}$} & \multirow{2}{*}{$\begin{array}{l}\text { Odds } \\
\text { Ratio }\end{array}$} \\
\hline & & \multicolumn{2}{|c|}{$\mathrm{Ya}$} & \multicolumn{2}{|c|}{ Tidak } & & & & \\
\hline & & $\mathrm{n}$ & $\%$ & $\mathrm{n}$ & $\%$ & $\mathrm{n}$ & $\%$ & \multirow{4}{*}{0,000} & \multirow[t]{4}{*}{0,070} \\
\hline 1 & Baik & 5 & 31,3 & 11 & 68,8 & 16 & 100 & & \\
\hline 2 & Kurang & 26 & 86,7 & 4 & 13,3 & 30 & 100 & & \\
\hline & Total & 31 & & 15 & & 46 & 100 & & \\
\hline
\end{tabular}

Berdasarkan hasil tabel diatas, dapat dilihat dari 16 responden yang termasuk kategori pengetahuan baik yang mengalami kecemasan pre op apendisitis berjumlah 5 responden $(31,3 \%)$. Dan dari 30 responden yang termasuk kategori pengetahuan kurang yang mengalami kecemasan pre op apendiksitis berjumlah 26 responden $(86,7 \%)$.

Dari uji statistik Chi-Square pada tingkat kemaknaan $\alpha=0,05$ diperoleh $\rho$-value $=$
0,000 yang berarti ada hubungan antara pengetahuan dengan kecemasan pada pasien pre op apendiksitis di ruang rawat inap rumah sakit daerah Siti Aisyah Kota Lubuklinggau tahun 2019, sehingga hipotesis yang menyatakan bahwa ada hubungan antara pengetahuan dengan kecemasan pada pasien pre op apendisitis terbukti secara statistik. Sedangkan hasil analisis statistik Odds Ratio didapatkan 0,070 artinya responden yang 
berpengetahuan baik berpeluang 0,070 kecemasan

kali untuk mengalami kejadian

Tabel 5.7

Distribusi Frekuensi Responden Berdasarkan Faktor Pendidikan Yang Mempengaruhi Kecemasan Pada Pasien Pre Op Apendiksitis di Ruang Rawat Inap Rumah Sakit Siti Aisyah

Kota Lubuklinggau

Tahun 2019

\begin{tabular}{|c|c|c|c|c|c|c|c|c|c|}
\hline \multirow[t]{3}{*}{ No } & \multirow[t]{3}{*}{ Pendidikan } & \multicolumn{4}{|c|}{$\begin{array}{c}\text { Kecemasan pada pasien pre } \\
\text { op apendkisitis }\end{array}$} & \multirow{2}{*}{\multicolumn{2}{|c|}{ Jumlah }} & \multirow{3}{*}{$\begin{array}{c}\rho \\
\text { value }\end{array}$} & \multirow{3}{*}{$\begin{array}{l}\text { Odds } \\
\text { Ratio }\end{array}$} \\
\hline & & \multicolumn{2}{|c|}{$\mathrm{Ya}$} & \multicolumn{2}{|c|}{ Tidak } & & & & \\
\hline & & $\mathrm{n}$ & $\%$ & $\mathrm{n}$ & $\%$ & $\mathrm{n}$ & $\%$ & & \\
\hline 1 & Tinggi & 8 & 44,4 & 10 & 55,6 & 18 & 100 & \multirow{3}{*}{0,019} & \multirow{3}{*}{$\begin{array}{r}0,174 \\
(0,045- \\
0.665)\end{array}$} \\
\hline 2 & Rendah & 23 & 82,1 & 5 & 17,9 & 28 & 100 & & \\
\hline & Total & 31 & & 15 & & 46 & 100 & & \\
\hline
\end{tabular}

Berdasarkan hasil tabel diatas, dapat dilihat dari 18 responden yang termasuk kategori pendidikan tinggi yang mengalami kecemasan pre op apendisitis berjumlah 8 responden $(44,4 \%)$. Dan dari 28 responden yang termasuk kategori pendidikan rendah yang mengalami kecemasan pre op apendisitis berjumlah 23 responden $(82,1 \%)$.

Dari uji statistik Chi-Square pada tingkat kemaknaan $\alpha=0,05$ diperoleh $\rho$-value $=$ 0,019 yang berarti tidak ada hubungan antara pendidikan dengan kecemasan pada pasien pre op apendisitis di ruang rawat inap rumah sakit daerah Siti Aisyah Kota Lubuklinggau tahun 2019, sehingga hipotesis yang menyatakan bahwa ada hubungan antara pendidikan dengan kecemasan pada pasien pre op apendisitis tidak terbukti secara statistik. Sedangkan hasil analisis statistik Odds Ratio didapatkan 0,174 artinya responden yang berpendidikan tinggi berpeluang 0,174 kali untuk mengalami kejadian kecemasan

Tabel 5.8

Distribusi Frekuensi Responden Berdasarkan Faktor Umur Yang Mempengaruhi Kecemasan Pada Pasien Pre Op Apendiksitis di Ruang Rawat Inap Rumah Sakit Siti Aisyah Kota Lubuklinggau Tahun 2019

\begin{tabular}{|c|c|c|c|c|c|c|c|c|c|}
\hline \multirow{4}{*}{ No } & \multirow{4}{*}{ Umur } & \multirow{2}{*}{\multicolumn{4}{|c|}{$\begin{array}{l}\text { Kecemasan pada pasien } \\
\text { pre op apendiksitis }\end{array}$}} & \multirow{3}{*}{\multicolumn{2}{|c|}{ Jumlah }} & \multirow{4}{*}{$\begin{array}{c}\rho \\
\text { value }\end{array}$} & \multirow{4}{*}{$\begin{array}{l}\text { Odds } \\
\text { Ratio }\end{array}$} \\
\hline & & & & & & & & & \\
\hline & & \multicolumn{2}{|c|}{$\mathrm{Ya}$} & \multicolumn{2}{|c|}{ Tidak } & & & & \\
\hline & & $\mathrm{n}$ & $\%$ & $\mathrm{n}$ & $\%$ & $\mathrm{n}$ & $\%$ & & \\
\hline 1 & Beresiko & 24 & 85,7 & 4 & 14,3 & 28 & 100 & \multirow{3}{*}{0,003} & \multirow{3}{*}{$\begin{array}{r}9,429 \\
(2,277- \\
39,035)\end{array}$} \\
\hline 2 & $\begin{array}{l}\text { Tidak } \\
\text { beresiko }\end{array}$ & 7 & 39,9 & 11 & 61,1 & 18 & 100 & & \\
\hline & Total & 31 & & 15 & & 46 & 100 & & \\
\hline
\end{tabular}


Berdasarkan hasil tabel diatas, dapat dilihat dari 28 responden yang termasuk kategori umur yang beresiko yang mengalami kecemasan pre op apendisitis berjumlah 24 responden $(87,7 \%)$. Dan dari 18 responden yang termasuk kategori umur yang tidak beresiko yang mengalami kecemasan pre op apendisitis berjumlah 7 responden $(38,9 \%)$.

Dari uji statistik Chi-Square pada tingkat kemaknaan $\alpha=0,05$ diperoleh $\rho$-value $=$ 0,003 yang berarti ada hubungan antara

Tabel 5.9

Distribusi Frekuensi Responden Berdasarkan Faktor Ekonomi Yang Mempengaruhi Kecemasan Pada Pasien Pre Op Apendisitis k di Ruang Rawat Inap Rumah Sakit Siti Aisyah Kota Lubuklinggau Tahun 2019

\begin{tabular}{|c|c|c|c|c|c|c|c|c|c|}
\hline \multirow{3}{*}{ No } & \multirow{3}{*}{ Ekonomi } & \multicolumn{4}{|c|}{$\begin{array}{l}\text { Kecemasan pada pasien } \\
\text { pre op apendiksitis }\end{array}$} & \multirow{2}{*}{\multicolumn{2}{|c|}{ Jumlah }} & \multirow{3}{*}{$\begin{array}{c}\rho \\
\text { valu } \\
\mathrm{e}\end{array}$} & \multirow{3}{*}{$\begin{array}{l}\text { Odds } \\
\text { Ratio }\end{array}$} \\
\hline & & \multicolumn{2}{|c|}{$\mathrm{Ya}$} & \multicolumn{2}{|c|}{ Tidak } & & & & \\
\hline & & $\mathrm{n}$ & $\%$ & $\mathrm{n}$ & $\%$ & $\mathrm{n}$ & $\%$ & & \\
\hline 1 & Tinggi & 8 & 40,0 & 12 & 60,0 & 20 & 100 & \multirow{3}{*}{0,002} & \multirow{3}{*}{$\begin{array}{r}0,087 \\
(0,019 \\
0,389)\end{array}$} \\
\hline 2 & Rendah & 23 & 88,5 & 3 & 11,5 & 26 & 100 & & \\
\hline & Total & 31 & & 15 & & 46 & 100 & & \\
\hline
\end{tabular}

Berdasarkan hasil tabel diatas, dapat dilihat dari 20 responden yang termasuk kategori ekonomi tinggi yang mengalami kecemasan pre op apendisitis berjumlah 8 responden $(40,0 \%)$. Dan dari 26 responden yang termasuk kategori ekonomi rendah yang mengalami kecemasan pre op apendisitis berjumlah 23 responden $(88,5 \%)$.

Dari uji statistik Chi-Square pada tingkat kemaknaan $\alpha=0,05$ diperoleh $\rho$-value $=$ umur dengan kecemasan pada pasien pre op apendiksitis di ruang rawat inap rumah sakit daerah Siti Aisyah Kota Lubuklinggau tahun 2019, sehingga hipotesis yang menyatakan bahwa ada hubungan antara umur dengan kecemasan pada pasien pre op apendisitis terbukti secara statistik. Sedangkan hasil analisis statistik Odds Ratio didapatkan 9,429 artinya responden yang umur beresiko berpeluang 9,429 kali untuk mengalami kejadian kecemasan
0,002 yang berarti ada hubungan antara ekonomi dengan kecemasan pada pasien pre op apendiksitis di ruang rawat inap rumah sakit daerah Siti Aisyah Kota Lubuklinggau tahun 2019, sehingga hipotesis yang menyatakan bahwa ada hubungan antara ekonomi dengan kecemasan pada pasien pre op apendisitis terbukti secara statistik. Sedangkan hasil analisis statistik Odds Ratio didapatkan 0,087 artinya responden yang ekonomi 
rendah berpeluang 0,087 kali untuk mengalami kejadian kecemasan.

\section{Analisa Multivariat.}

Analisa ini untuk mencari Hubungan variabel indevenden yang paling dominan berhubungan dengan variabel devenden.Analisis multivariat menggunakan uji regresi logistik ganda.

Tabel 5.10

Hasil Analisis Bivariat Antara Variabel Pengetahuan, Pendidikan, Umur dan Ekonomi Dengan Kecemasan Pada Pasien Pre Op Apendisitis di Ruang Rawat Inap Rumah Sakit Siti Aisyah Kota Lubuklinggau Tahun 2019

\begin{tabular}{|c|l|c|c|c|}
\hline No & \multicolumn{1}{|c|}{ Variabel } & - 2 Log Likelihood & G & P value \\
\hline 1 & Pengetahuan & 43,435 & 14,651 & 0,000 \\
\hline 2 & Ekonomi & 45,517 & 12,569 & 0,000 \\
\hline 3 & Umur & 47,023 & 11,063 & 0,001 \\
\hline
\end{tabular}

Berdasarkan tabel 5.10 dapat diketahui bahwa semua variabel penelitian mempunyai nilai $\mathrm{p}<0,25$ yang berarti semua variabel penelitian merupakan kandidat untuk diikutsertakan dalam analisis multivariat

\section{Pembuatan Model Faktor Penentu}

\section{Kecemasan pasien}

Dalam pemodelan ini semua variable kandidat dicobakan secara bersama-sama untuk mencari factor penentu kecemasan pasien. Model yang terbaik akan mempertimbangkan pada nilai signifikansi rasio Log-likelihood ( $p$ $\leq 0,05)$ dan nilai signifikan $\mathrm{p}$ Wald $(p \leq$ $0,05)$. Pemilihan model dilakukan secara hirarki dengan cara semua variabel independen yang memenuhi syarat sebagai kandidat dimasukkan ke dalam model, kemudian variabel yang nilai $p$ nya terbesar dikeluarkan secara berurutan dari permodelan dimulai dari nilai $\mathrm{p}$ Wald yang terbesar. (Hastono, 2001). 
1. Model Pertama

Tabel 5.11

Hasil Analisis Multivariat Regresi Logistik Antara Variabel Pengetahuan, Pendidikan, Umur Dan EkonomiDengan Kecemasan Pasien Pre Op Apendisitis Di Ruang Rawat Inap Rumah Sakit Siti Aisyah Kota Lubuklinggau Tahun 2019

\begin{tabular}{|l|c|c|c|l|}
\hline \multicolumn{1}{|c|}{ Variabel } & B & P & $\begin{array}{c}\text { OR / } \\
\operatorname{Exp}(\mathbf{B})\end{array}$ & 95\% CI \\
\hline Pengetahuan & 20,601 & 0,998 & 8,851 & $0,000-0$ \\
\hline Pendidikan & 21,120 & 0,998 & 0,000 & $0,000-0$ \\
\hline Umur & 1,003 & 0,376 & 3,276 & $0,296-25,115$ \\
\hline Ekonomi & 2,281 & 0,096 & 0,102 & $0,007-1,494$ \\
\hline
\end{tabular}

-2 $\log$ Likehood $=22,046 \quad G=36,040 \quad$ p Value $=0,000$

Berdasarkan tabel 5.11 bahwa variabel Pengetahuan dan pendidikan mempunyai nilai $p$ terbesar, sehingga harus dikeluarkan dari model. Analisis selanjutnya dengan tidak mengikutsertakan variabel pengetahuan dan pendidikan.

\section{Model Kedua}

Tabel 5.12

Hasil Analisis Multivariat Regresi Logistik Antara Variabel Umur Dan EkonomiDengan Kecemasan Pasien Pre Op Apendisitis Di Ruang Rawat Inap Rumah Sakit Siti Aisyah Kota Lubuklinggau Tahun 2019

\begin{tabular}{|l|c|c|c|c|}
\hline \multicolumn{1}{|c|}{ Variabel } & B & P & $\begin{array}{c}\text { OR/ } \\
\operatorname{Exp}(\mathbf{B})\end{array}$ & $\mathbf{9 5 \%} \mathbf{C I}$ \\
\hline Umur & 1,636 & 0,040 & 5,135 & $1,079-24,446$ \\
\hline Ekonomi & 1,912 & 0,020 & 0,148 & $0,030-0,737$ \\
\hline
\end{tabular}

$-2 \log$ Likehood = 41,192 G=16,894

$$
\text { p Value }=0,000
$$

Hasil analisis tersebut diatas hubungan signifikan dengan kecemasan menunjukkan bahwa semua variabel mempunyai nilai $\mathrm{p}<0,05$, yang berarti variabel umur dan ekonomi mempunyai pada pasien pre op apendisitis di ruang Rawat Inap Rumah Sakit Siti Aisyah Kota Lubuklinggau Tahun 2019

\section{Uji Interaksi}

Dalam analisis interaksi, pemilihan variabel yang berinteraksi antar variabel independen didasarkan substansi.Berdasarkan variabel yang masuk model multivariat, maka interaksi yang memungkinkan adalah variabel Ekonomi dengan Umur (Ekonomi *Umur). Hasil uji interaksi seperti terlihat pada table 5.13 
Tabel 5.13

Uji Interaksi Variabel Ekonomi Dan UmurDengan Kecemasan Pasien Pre Op Apendisitis Di Ruang Rawat Inap Rumah Sakit Siti Aisyah Kota Lubuklinggau

Tahun 2019

\begin{tabular}{|c|c|c|c|}
\hline INTERAKSI & $\mathbf{- 2}$ Log Likehood & G & Nilai P \\
\hline Ekonomi * Umur & 21,401 & 36,686 & 0,000 \\
\hline
\end{tabular}

Dari uji interaksi diatas, terlihat artinya ada interaksi antara Ekonomi bahwa $\mathrm{p}=0,000(\mathrm{p}>0,05)$ yang dan Umur.

\section{Penentuan Model Akhir}

Pemodelan selesai model yang valid pada penelitian ini adalah model dengan interaksi. Hasil analisis model akhir seperti pada table 5.14 di bawah ini:

Tabel 5.14

Hasil Analisis Multivariat Regresi Logistik Antara Variabel Umur Dan EkonomiDengan Kecemasan Pasien Pre Op Apendisitis Di Ruang Rawat Inap Rumah Sakit Siti Aisyah Kota Lubuklinggau Tahun 2019

\begin{tabular}{|c|c|c|c|c|c|}
\hline No & VARIABEL & B & P & $\begin{array}{c}\text { OR / } \\
\operatorname{Exp}(\mathbf{B})\end{array}$ & $\mathbf{9 5 \% ~ C I ~}$ \\
\hline 1 & Ekonomi & 1,912 & 0,020 & 0,148 & $0,030-0,737$ \\
\hline 2 & Umur & 1,636 & 0,040 & 5,135 & $1,079-24,446$ \\
\hline \multicolumn{2}{r|}{-2 Log Likehood $=\mathbf{4 1 , 1 9 2}$} & $\mathbf{G = 1 6 6 , 8 9 4}$ & \multicolumn{2}{c|}{ p Value $=\mathbf{0 , 0 0 0}$}
\end{tabular}

Dari keseluruhan proses analisis yang telah dilakukan dapat disimpulkan bahwa dari 4 variabel independen yang diduga berhubungan dengan kecemasan pasien pre op apendisitis, ternyata hanya dua variabel yang secara signifikan berhubungan dengan kecemasan pasien pre op apendisitis yaitu variabel Ekonomi dan Umur.

Responden yang mempunyai ekonomi tinggi mempunyai peluang 0,148 kali ( $95 \%$ CI : 0,030 - 0,737) untuk tidak mengalami kecemasan dibandingkan responden yang mempunyai ekonomi rendah. Responden yang mempunyai umur beresiko mempunyai peluang 5,135 kali ( 95\% CI : 1,079 - 24,446), untuk mengalami kecemasan dibanding dengan responden yang tidak mengalami resiko. Selanjutnya dapat disimpulkan bahwa dari dua variabel tersebut ternyata variabel umur merupakan variabel yang paling dominan berhubungan dengan kecemasan pasien pre op apendisitis dengan nilai Exp (B) labih besar $(5,135)$. 


\section{PEMBAHASAN}

a. Tingkat kecemasan pada pasien pre op apendiksitis di ruang rawat inap rumah sakit daerah Siti Aisyah Kota Lubuklinggau tahun 2019

Berdasarkan tabel distribusi kecemasan pada pasien pre op apendisitis didapatkan bahwa sebagian besar responden mempunyai tingkat kecemasan yaitu sebanyak 31 responden (67.4\%).

Menurut (Stuart \& Sundeen, 2011) faktor-faktor yang mempengaruhi kecemasan ada 2 (dua) yaitu faktor predisposisi dan faktor presipitasi, dari faktor presipitasi seperti: Ancaman integritas diri. Meliputi ketidakmampuan fisiologis atau gangguan terhadap kebutuhan dasar.Hal ini dipengaruhi oleh faktor eksternal seperti lingkungan dan ekonomi, dan faktor internal seperti pengetahuan, pendidikan dan umur. Dan Ancaman sistem diri. Meliputi ancaman terhadap identitas diri, harga diri dan hubungan interpersonal, kehilangan serta perubahan status atau peran.Faktor eksternal yang mempengaruhi harga diri adalah kehilangan, dilematik, tekanan dalam kelompok sosial maupun budaya.
Menurut Ellis (2014). Tindakan operasi sering menyebabkan kecemasan pada pasien.Menanggulangi atau menurunkan kecemasan pasien adalah salah satu tugas perawat. Salah satu caranya yaitu dengan komunikasi. Misalnya penjelasan tentang prosedur tindakan. Fenomena yang ada sekarang, bahwa komunikasi yang dilakukan perawat sebagai orang yang terdekat dan paling lama berada di dekat pasien cenderung mengarah pada tugas perawat dari pada mengenali kecemasan dan persepsi pasien tentang tindakan yang menyebabkan kecemasan.

Kecemasan adalah perasaan yang difius, yang sangat tidak menyenangkan, agak tidak menentu dan kabur tentang sesuatu yang akan terjadi. Perasaan ini disertai dengan suatu atau beberapa reaksi badaniah yang khas dan yang akan datang berulang bagi seseorang tertentu. Perasaan ini dapat berupa rasa kosong di perut, dada sesak, jantung berdebar, keringat berlebihan, sakit kepala atau rasa mau kencing atau buang air besar.(Rawling, 2014).

Hasil penelitian ini tidak jauh berbeda dengan hasil penelitian yang dilakukan oleh Hanna, (2009) yang berjudul "hubungan pengetahuan dan sikap orang tua dengan kecemasan yang terjadi pada pasien operasi di ruang 
rawat inap rumah sakit $\mathrm{M}$ Yunus Kota Bengkulu" menunjukkan bahwa sebagian besar pasien mengalami kecemasan yaitu berjumlah 87,3\% responden dan yang tidak mengalami kecemasan hanya ada $12,7 \%$ responden.

b. Hubungan pengetahuan dengan kecemasan pada pasien pre op apendiksitis di ruang rawat inap rumah sakit daerah Siti Aisyah Kota Lubuklinggau tahun 2019.

Berdasarkan tabel 5.1 distribusi pengetahuan pasien didapatkan bahwa sebagian besar responden mempunyai tingkat pengetahuan yang kurang yaitu sebanyak 30 responden (652\%).

Berdasarkan hasil tabel diatas, dapat dilihat dari 16 responden yang termasuk kategori pengetahuan baik yang mengalami kecemasan pre op apendisitis berjumlah 5 responden (31,3\%). Dan dari 30 responden yang termasuk kategori pengetahuan kurang yang mengalami kecemasan pre op apendisitis berjumlah 26 responden $(86,7 \%)$.

Dari uji statistik Chi-Square pada tingkat kemaknaan $\alpha=0,05$ diperoleh $\rho$ value $=0,000$ yang berarti ada hubungan antara pengetahuan dengan kecemasan pada pasien pre op apendisitis di ruang rawat inap rumah sakit daerah Siti
Aisyah Kota Lubuklinggau tahun 2019, sehingga hipotesis yang menyatakan bahwa ada hubungan antara pengetahuan dengan kecemasan pada pasien pre op apendisitis terbukti secara statistik.

Hasil penelitian ini sejalan dengan pendapat Notoatmodjo (2008) yang mengatakan bahwa pengetahuan itu merupakan salah satu faktor yang menyebabkan seseorang berprilaku. Selain itu juga Notoatmodjo mengungkapkan pengetahuan adalah pemberian bukti oleh seseorang melalui proses pengingatan atau pengenalan informasi, ide dan fenomena sebelumnya melalui penginderaan terhadap objek tertentu dan prilaku yang didasari pengetahuan yang baik akan lebih lenggang dari pada prilaku yang tidak didasari pengetahuan.

Pada hasil penelitian ini pasien yang mempunyai pengetahuan yang baik tentu mampu memahami penjelasan dari dokter maupun perawat tentang tindakan operasi yang akan dilakukan, dengan bertambahnya pemahaman tentu akan dapat mengurangi rasa kecemasan yang dimiliki oleh pasien.

c. Hubungan pendidikan dengan kecemasan pada pasien pre op apendiksitis di ruang rawat inap 
rumah sakit daerah Siti Aisyah Kota

Lubuklinggau tahun 2019.

Berdasarkan tabel 5.2 distribusi tingkat pendidikan pasien didapatkan bahwa sebagian besar responden mempunyai tingkat pendidikan yang tinggi yaitu sebanyak 28 responden $(57.1 \%)$.

Berdasarkan hasil tabel diatas, dapat dilihat dari 18 responden yang termasuk kategori pendidikan tinggi yang mengalami kecemasan pre op apendisitis berjumlah 8 responden (44,4\%). Dan dari 28 responden yang termasuk kategori pendidikan rendah yang mengalami kecemasan pre op apendisitis berjumlah 23 responden $(82,1 \%)$.

Dari uji statistik Chi-Square pada tingkat kemaknaan $\alpha=0,05$ diperoleh $\rho$ value $=0,019$ yang berarti tidak ada hubungan antara pendidikan dengan kecemasan pada pasien pre op apendisitis di ruang rawat inap rumah sakit daerah Siti Aisyah Kota Lubuklinggau tahun 2097, sehingga hipotesis yang menyatakan bahwa ada hubungan antara pendidikan dengan kecemasan pada pasien pre op apendiksitis tidak terbukti secara statistik.

Hasil penelitian ini tidak sesuai dengan teori yang diungkapkan oleh Ahmadi (2016) yang menyatakan bahwa pendidikan sangat berpengaruh dalam mengambil sikap, semakin tinggi pendidikan semakin matang dalam bertindak.Semakin tinggi pendidikan maka semakin memudahkan untuk menerima dan menangkap informasi yang disampaikan. Pendidikan adalah kegiatan untuk memperbaiki kemampuan seseorang dengan cara meningkatkan bukan hanya pengetahuan akan tetapi juga keterampilan.

Terjadinya ketidak sesuaian antara hasil penelitian ini dengan teori yang ada kemungkinan dapat disebabkan oleh adanya faktor lain, seperti faktor pengalaman, jenis kelamin dan lain-lain, karena hasil penelitian ini menunjukkan dari 28 responden yang termasuk kategori pendidikan tinggi yang mengalami kecemasan pre op apendisitis berjumlah 23 responden $(82,1 \%)$. Hal ini terjadi karena walaupun pasien sudah mempunyai pendidikan yang tinggi tetapi pasien belum pernah ada pengalaman tentang tindakan operasi, hal ini juga dapat mempengaruhi tingkat kecemasan pasien.

Hasil penelitian ini juga sesuai dengan hasil penelitian yang dilakukan oleh Qirana, (2017) yang berjudul "hubungan pendidikan dengan tingkat kecemasan pasien sebelum dilakukan tindakan operasi di ruang operasi rumah sakit dr. Sobirin Kabupaten Musi 
Rawas". Hasil yang didapat yaitu $\rho$ value $=0,847$ yang berarti tidak ada hubungan yang bermakna antara pendidikan dengan tingkat kecemasan pasien sebelum dilakukan tindakan operasi di ruang operasi rumah sakit dr. Sobirin Kabupaten Musi Rawas.

d. Hubungan umur dengan kecemasan pada pasien pre op apendiksitis di ruang rawat inap rumah sakit daerah Siti Aisyah Kota Lubuklinggau tahun 2019.

Berdasarkan tabel 5.3 distribusi tingkatan umur pasien didapatkan bahwa sebagian besar responden mempunyai tingkatanumur yang beresiko yaitu sebanyak 28 responden $(60,9 \%)$.

Berdasarkan hasil tabel diatas, dapat dilihat dari 28 responden yang termasuk kategori umur yang beresiko yang mengalami kecemasan pre op apendisitis berjumlah 24 responden $(85,7 \%)$. Dan dari 18 responden yang termasuk kategori umur yang tidak beresiko yang mengalami kecemasan pre op apendiksitis berjumlah 7 responden $(38,9 \%)$.

Dari uji statistik Chi-Square pada tingkat kemaknaan $\alpha=0,05$ diperoleh $\rho$ value $=0,003$ yang berarti ada hubungan antara umur dengan kecemasan pada pasien pre op apendisitis di ruang rawat inap rumah sakit daerah Siti Aisyah Kota Lubuklinggau tahun 2019, sehingga hipotesis yang menyatakan bahwa ada hubungan antara umur dengan kecemasan pada pasien pre op apendiksitis terbukti secara statistik.

Berdasarkan hasil penelitian ini terlihat jelas bahwa pasien yang mempunyai fakor umur yang beresiko akan mengalami tingkat kecemasan yang lebih tinggi hal ini terjadi karena pasien merasa bahwa faktor umur yang masih muda dan belum mempunyai pengalaman tentang tindakan operasi tentu hal ini akan meningkatkan kecemasan pasien.

e. Hubungan ekonomi dengan kecemasan pada pasien pre op apendiksitis di ruang rawat inap rumah sakit daerah Siti Aisyah Kota Lubuklinggau tahun 2019.

Berdasarkan tabel 5.4 distribusi tingkat ekonomi pasien didapatkan bahwa sebagian besar responden mempunyai tingkat ekonomi yang rendah yaitu sebanyak 26 responden $(56,6 \%)$.

Berdasarkan hasil tabel diatas, dapat dilihat dari 20 responden yang termasuk kategori ekonomi tinggi yang mengalami kecemasan pre op apendisitis berjumlah 8 responden $(540,0 \%)$. Dan dari 26 
responden yang termasuk kategori ekonomi rendah yang mengalami kecemasan pre op apendisitis berjumlah 23 responden $(88,5 \%)$.

Dari uji statistik Chi-Square pada tingkat kemaknaan $\alpha=0,05$ diperoleh $\rho$ value $=0,002$ yang berarti ada hubungan antara ekonomi dengan kecemasan pada pasien pre op apendiksitis di ruang rawat inap rumah sakit daerah Siti Aisyah Kota Lubuklinggau tahun 2019, sehingga hipotesis yang menyatakan bahwa ada hubungan antara ekonomi dengan kecemasan pada pasien pre op apendisitis terbukti secara statistik.

Menurut Elfindri, (2013) keluarga berpenghasilan rendah mempunyai kondisi yang kurang menguntungkan baik fisik maupun non fisik dalam menjamin status kesehatan yang optimal bagi anggota keluarganya dibandingkan kelompok berpenghasilan tinggi. Ekonomi yang sudah mapan dapat memenuhi kebutuhan sehari-hari untuk menunjang dalam mencapai derajat kesehatan yang optimal. Rendahnya tingkat ekonomi akan mempengaruhi pengetahuan akan perlindungan diri sendiri, seseorang akan dapat mengkomsumsi barang dan jasa dibatasi oleh besarnya pendapatan.

Hasil penelitian ini sesuai dengan teori karena pasien yang mempunyai tingkat ekonomi yang rendah tentu akan mengalami tingkat kecemasan yang tinggi juga yaitu $88,5 \%$, hal ini terjadi karena pasien merasa khawatir dengan tindakan operasi yang dilakukan yang sudah pasti memerlukan biaya yang sangat mahal sedangkan pasien tidak mempunyai uang untuk membayar biaya tersebut.

Analisa multivariat dilakukan untuk memperoleh variabel yang paling dominan atau variabel yang mempunyai pengaruh paling besar terhadap kecemasan pada pasien pre op apendiksitis dengan menggunakan metode regresi logistik,yaitu salah satu penedekatan model matematis yang digunakan untuk menganalisis hubungan satu atau beberapa variabel independen dengan sebuah variabel dependen yang katagorik bersifat dikotom atau binori.Variabel karagorik yang dikotom adalah variabel yang mempunyai dua nilai variasi. Dari hasil analisis logistik pada model akhir diperoleh dua variabel yang berhubungan signifikan dengan kecemasan pasien pre op operasi apendiksitis.Kedua variebel yang paling dominan/paling besar pengaruhnya terhadap masan pasien pre op operasi apendiksitis adalah variabel Umur dimana dpat dilihat nilai Exp (B) nya yang paling besar yaitu 5,135. Variabel 
umur setelah dilakukan analisis multivariat dan setelah diseleksi dengan variabel independen lain secara statistik tetap mempunyai hubungan yang signifikan dimana OR $=5,135(95 \% \mathrm{CI}$ $: 1,079-24,446$ ) $\mathrm{p}$ value $=0,040$, artinya bahwa pasein yang mempunyai umr beresiko mempunyai peluang 5,135 kali untu mengalami kecemasan dibandingkan pasien yang mempunyai umur tidak beresiki setelah di control oleh variabel ekonomi,artinya variabel umur secara simultan dengan variabel ekonomi mempengaruhi kecemasan pasien pre op operasi apendiksitis di ruang rawat inap rumah sakit daerah Siti Aisyah Kota Lubuklinggau tahun 2019

\section{KESIMPULAN}

Dari hasil penelitian tentang Analisis Kecemasan Pada Pasien Pre Operasi Apendisitis Di Ruang Rawat Inap Rumah Sakit Umum Daerah Siti Aisyah Kota Lubuklinggau Tahun 2019dapat disimpulkan sebagai berikut :

a. Ada hubungan antara faktor pengetahuan,pendidikan,umur dan ekonomi secara simultan dengan kecemasan pada pasien pre operasi apendiksitis di Rumah Sakit Umum Daerah Siti Aisyah Kota lubuklinggau Tahun 2019 b. Ada hubungan antara faktor pengetahuan secara parsial dengan kecemasan pada pasien pre operasi apendiksitis di Rumah Sakit Umum Daerah Siti Aisyah Kota lubuklinggau Tahun 2019

c. Ada hubungan antara faktor pendidikan secara parsial dengan kecemasan pada pasien pre operasi apendiksitis di Rumah Sakit Umum Daerah Siti Aisyah Kota lubuklinggau Tahun 2019

d. Ada hubungan antara faktor umur secara parsial dengan kecemasan pada pasien pre operasi apendiksitis di Rumah Sakit Umum Daerah Siti Aisyah Kota lubuklinggau Tahun 2019

e. Ada hubungan antara faktor Ekonomi secara parsial dengan kecemasan pada pasien pre operasi apendiksitis di Rumah Sakit Umum Daerah Siti Aisyah Kota lubuklinggau Tahun 2019

f. Hasil Uji statistik multivariat yaitu diperoleh variabel yang berhubungan bermakna secara simultan dengan kecemasan pasien pre op operasi apendiksitis di Ruang Rawat Inap Rumah Sakit Siti Aisyah Kota Lubuklinggau adalah variabel umur dan ekonomi.Dari Hasil pemdelan bahwa responden yang 
mempunyai umur yang beresiko mempunyai peluang 5,135 kali untuk mengalami kecemasan pada saat akan menjalani tindakan operasi dibandinkan dengan resonden yang mempunyai umur yang tidak beresiko setelah dikontrol dengan variabel ekonomi.

g. Variabel yang palin dominan berhubungan dengan kecemasan pasien pre op operasi apendiksitis di ruang rawat inap Rumah Sakit Umum Daerah Siti Aisyah Kota Lubuklinggau adalah variabel dengan nilai Exp ( B ) lebih besar ( 5,135 ) mempunyai tingkat ekonomi yang rendah yaitu sebanyak 22 responden $(52.4 \%)$.

\section{SARAN}

\section{Bagi Direktur Rumah Sakit Siti Aisyah Kota Lubuklinggau}

Sebagai bahan masukan bagi Rumah Sakit Umum Daerah Siti Aisyah Kota Lubuklinggau, khususnya bagi perawat untuk meningkatkan kinerja perawat dalam mencegah atau mengurangi kecemasan pasien sebelum dilakukan operasi apendicitis.dan untuk perawat diharapkan dapat mengaplikasikan asuhan keperawatan dan pengembangan model-model intervensi keperawatan lainnya khususnya dalam menangani kecemasan pada pasien op operasi apendiksitis yang ada di rumah sakit.

\section{DAFTAR PUSTAKA}

1. Arikunto,S. 2003Prosedur penelitian Suatu Pendekatan Praktek. Edisi

Revisi V, Rineka Cipta, Jakarta.

2. Badan Pusat Statistik, 2017 Upah minimum provinsi. Diakses darihttp://www.blogspot.com.

3. Brunner, Suddarth, 2011 Buku Ajar Keperawatan-Medikal Bedah, Edisi 8 Volume 3, EGC : Jakarta

4. Elfindri, 2013. Propil Kesehatan. Diakses dari http://www.blogspot.com.

5. Juliardinsyah. 2015 Askep Apendisitis.Diakses dari http://juliardisyah.blogspot.com/201 5/ 11/askep-apendisitis.html

6. Ludeman.2015.The pathology of diverticular disease. Diakses dari http://linkinghub.elsevier.comretrieve /pii/S1521691802902970.Februari 2017.

7. Mansjoer Arif, dkk. 2008. Kapita Selekta Kedokteran. Jilid 2. Jakarta. Media Aesculapius

8. Mundakir, 2006 Komunikasi keperawatan (Aplikasi dalam pelayanan). Yogyakarta. Graha Medika 
9. Notoatmodjo, 2008. Metodologi Penelitian Kesehatan. Rineka Cipta. Jakarta

10. 2012. Pendidikkan dan kesehatan untuk penelitian mahasiswa. Rineka Cipta. Jakarta

11. Nursalam. 2008. Konsep \& Penerapan Metodologi Penelitian Ilmu Keperawatan. Salemba Medika.Jakarta

12. Padila, $2012 \quad B u k u \quad$ ajar keperawatan medikal bedah. Yogyakarta. Nuha medika

13. Rumah Sakit Daerah Siti Aisyah, 2017.Medical Record rumah sakit Daerah Siti Aisyah Lubuklinggau tahun 2019

14. Sjamsuhidajat, R. \& Jong, W.D. 2014. Buku Ajar Ilmu Bedah, edisi revisi. EGC.Jakarta

15. Smaltzer. 2001. Keperawatan Medikal Bedah Edisi 8, Vol 2. EGC. Jakarta

16. Efendi,2008,Pendidikan dan Perilaku,Diakses dari http/www.blokspot.com

17. Ellis.R.2014.Kapita Selkta Penyakit.Jakarta.EGC.

18. Padila,2015.Buku ajar keperawatan medikal bedah.YogjakartaNuha medika

19. Rui,2017.Patofisiologi:Konsep Klinik Proses Penyakit.Jakarta EGC
20. Saber,2016,Profil Pembangunan Kesehatan Indonesia.Jakarta.

21. Standar Diagnosis keperawatan Indonesia,2017.Defensisi dan indikator diagnostik.Edisi.I Jakarta: DPP PPNI 